\title{
Slow Food - A existência além do combate ao fast food, as questões culturais e ambientais do movimento.
}

\section{Natália S. Cruz (IC)}

\section{Resumo}

O Movimento Slow Food foi criado para combater o Fast Food e a alimentação industrializada. Inclui em sua filosofia o direito ao prazer da alimentação, com produtos artesanais de qualidade, produzidos de forma que respeite o meio ambiente e as pessoas. A partir da visão geral sobre o movimento procurou-se entender como atuou na cidade de Campinas.

Palavras chave: slow food, meio ambiente, pessoas.

\section{Introdução}

A pesquisa partiu dos princípios defendidos pelo Slow Food, do direito à alimentação prazerosa, boa e com produtos que respeitem o meio ambiente e as culturas locais e tentou verificar como eles são aplicados no convivium ${ }^{i}$ Campinas. Foram acompanhadas reuniões, feiras e jantares promovidos pelo movimento campineiro. No entanto, ao longo da pesquisa, o convivium deixou de realizar atividades e até o presente momento encontra-se inativo. Diante disso, a pesquisa caminhou para descobrir o quão efetiva foram as ações realizadas na cidade e se, de fato, a população passou a conhecer os valores do Slow Food, já que era uma das metas do convivium campineiro disseminar as ideias e colocar em contato consumidores e produtores.

\section{Resultados e Discussão}

A intenção era pesquisar em três grupos distintos os conhecimentos acerca do movimento e os princípios que regem as ações do Slow Food, tanto no Brasil, quanto no mundo. Os três grupos selecionados foram: estudantes de gastronomia e cursos de culinária, frequentadores de feiras e lojas de produtos orgânicos e a população em geral. Foram obtidos os seguintes dados: Estudantes: $82,3 \%$ conhecem o Slow Food e $17,7 \%$ não conhecem. Consumidores: $66,1 \%$ conhecem o movimento, enquanto, 33,9\% não conhecem. Sociedade: $20,4 \%$ conhecem o slow food e $79,6 \%$ não conhecem.

\section{Conclusões}

A partir da análise desses dados, foi possível concluir que estudantes de gastronomia e consumidores de produtos orgânicos possuem maior conhecimento sobre os valores do Slow
Food. Ainda segundo os dados, é possível afirmar que isso acontece por terem contato com a gastronomia e a filosofia dos orgânicos, espaços em que as ideias do Slow Food circulam com prestígio. Entre a população em geral, poucos conhecem o movimento, no entanto, os que afirmaram conhecer, descobriram o movimento a partir das ações do Slow Food Campinas.

Ainda é possível concluir que, mesmo com uma atuação breve, o movimento conseguiu disseminar os princípios a um pequeno número de pessoas. Provavelmente, se as atividades propostas tivessem continuidade, um número maior de pessoas não ligadas a gastronomia ou ao consumo de orgânicos pudesse entender sobre importância que produtos regionais tem na manutenção da cultura gastronômica local e na preservação ambiental de áreas no entorno da cidade.

\section{Agradecimentos}

Ao Cnpq, por financiar a primeira e última parte da pesquisa, ao SAE, pelo financiamento da etapa intermediária. Aos colegas da gastronomia, que deram grande apoio e sempre que possível, colaboraram com discussões sobre o assunto, a orientadora Leila Algranti, que aceitou colaborar com a orientação de um assunto ainda tão novo no meio acadêmico, minha imensa gratidão, ao colega Leandro Forner, meu muito obrigada. Por fim, a minha família, minha eterna gratidão, por permitirem que eu caminhasse entre a sociologia e a gastronomia.

${ }^{1}$ IRVING, John;PETRINI, Carlo. Bem Vindos ao Nosso Mundo- O Manual Slow Food. Turim, Stargrafica,2008.

PETRINI, Carlo; BOTINI, Renata Lucia. Slow food: princípios da nova gastronomia. São Paulo, Editora Senac, 2005. PORTINARI, Folco. Manifesto Slow Food. Bra, 1989

\footnotetext{
O termo convivium vem do latim e quer dizer festim, entretenimento, um banquete. Os conviviuns são grupos autônomos locais responsáveis pela vida e propagação do slow food, são responsáveis por articular as relações entre produtores, promover campanhas de proteção aos alimentos e práticas tradicionais. Convivium. Categoria: Sobre o Slow Food. 2007.Disponivel em: <http://www.slowfoodbrasil.com/convivium>
} 